\title{
Serotypes of Salmonella in Broiler Carcasses Marketed at Ibague, Colombia.
}

\section{-Author(s)}

\section{Rodriguez $\mathrm{JM}^{\prime, 1}$ \\ Rondón IS,III}

Verjan $\mathrm{N}^{\prime \prime}$

Research Group in Poultry Science, Faculty of Veterinary Medicine and Zootechny, University of Tolima, Altos de Santa Helena A.A. 546, Ibagué, Tolima Colombia.

" Immunobiology and Pathogenesis Research Group, Faculty of Veterinary Medicine and Zootechny, University of Tolima, Altos de Santa Helena A.A. 546, Ibagué, Tolima.

\section{aMail Address}

Corresponding author e-mail address Noel Verjan García, PhD

Departamento de Sanidad Animal Faculty of Veterinary Medicine and Zootechny University of Tolima

Santa Helena, Parte Alta, Ibagué, Tolima, Colombia - A.A. 546

Phone: (57) 3203847233

Email: nverjang@ut.edu.co

\section{aKeywords}

Isolation, poultry, prevalence, risk factors, serotyping.

\section{ABSTRACT}

Salmonella enterica is a large group of Gram-negative bacteria responsible for a number of foodborne infections associated with the consumption of contaminated poultry products. The hygienic status of raw chicken meat marketed at Ibague, Tolima, Colombia, is currently unknown. To address this issue, a cross-sectional study was conducted to estimate the prevalence of Salmonella spp., in raw chicken marketed at different outlets in this city. Salmonella spp. was isolated by standard microbiological methods, followed by biochemical, serological, and molecular confirmation. Additionally, risk factors associated with the presence of the bacteria were identified. The prevalence of Salmonella in raw chicken was $17.41 \%(47 / 270)$, and 14 different serotypes were found, out of which S. Paratyphi B (36.17\%), S. Hvittingfoss (19.15\%) and $S$. Muenster (10.64\%) were the most prevalent and represented $65.95 \%$ of all serotypes. Amplification of 284 bp of the invA gene was achieved by PCR in a number of randomly selected isolates. Raw chicken as the only type of meat sold at stores (odds ratio: 2,157, p<0.05), and stainless steel as a contact surface of chicken meat (odds ratio: 13,29, $p<0.05)$, were found to be potential risk factors for the presence of Salmonella in chicken meat. This work serves as a reference about the current status of Salmonella in chicken meat marketed in Ibague, Tolima, Colombia, and indicates the need to establish appropriate control and contingency measures to minimize the presence of the bacteria in raw chicken to prevent its transmission to humans.

\section{INTRODUCTION}

The genus Salmonella is a group of Gram-negative bacteria belonging to the Enterobacteriaceae family that cause food poisoning in humans worldwide. Two species are recognized within this genus; S. enterica and S. Bongori and today more than 2,600 serotypes have been described. Importantly, about 93.8 million illnesses, of which 80.3 million are foodborne and 115,000 deaths each year are caused by non typhoidal Salmonella (Majowicz et al. 2010), where raw chicken meat has been recognized as a significant source of human salmonellosis (Mercado et al. 2012; Yang et al. 2010). Salmonella can infect birds in different steps of the production chain including live production (e.g. breeding and broiler farms), where it can induce clinical symptoms or an asymptomatic infection (Barua et al. 2013; Carrasco et al. 2012; Ibrahim et al. 2014). Salmonella may also be present in processing plants and in further-processing plants, where cross-contamination between carcasses by contact with feces or by sharing materials used in processing may occur (Carrasco et al. 2012). Additionally, the bacterium has been reported in end products, such as meat and eggs sold to consumers (El-Aziz, 2013; Tammakritsada \& Todhanakasem, 2012; Zhu et al. 2014). 
Salmonellosis in humans is characterized by fever, diarrhea and acute abdominal pain that maybe a self-limiting gastrointestinal infection, such as those caused by serotypes Typhimurium and Enteritidis (Mercado et al. 2012; Santos et al. 2001); however, when the bacteria enter the bloodstream it can be life-threatening (Gómez \& Zuñiga, 2005; Jiménez et al. 2011). Nevertheless, the virulence factors expressed by the bacteria and the immune status of the patient may be critical in determining the clinical form of the disease. The serotypes S. Infantis, S. Newport, and $S$. Hadar are commonly isolated from poultry and represent potential risks to human health since they have recently been associated with Salmonella outbreaks by direct contact with live birds (Centers of Disease Control and Prevention, 2014). In addition, strains of $S$. Java and Schwarzengrund have been isolated from chicken meat, presenting pulsed field gel electrophoresis patterns identical to those isolates from humans, strongly suggesting that the poultry carcasses maybe the source of infection (Brown et al. 2003; Chen et al. 2012).

Poultry products are well-known sources of Salmonella infection to humans and preventive measures on the farm need to be established to begin its control. Control programs for Salmonella have proven to be efficient to reduce economic losses (INFOSAN, 2005). In Colombia, limited information is available on the status of Salmonella species circulating in poultry products and those responsible for human infections. Recently, Salmonella serotype Typhimurium variant 5 was isolated from human cases of salmonellosis in Paz del Rio, Boyacá (Díaz et al., 2014). However, most of the cases are not reported to the medical centers and underreporting of cases of bacterial gastroenteritis predominates. In addition, people do not always go to a health centers and usually they are treated as outpatients without any clinical analysis and laboratory isolation. This situation is worsened by reports of emerging multidrug resistant enterobacteria causing huge economic losses to the health system and compromising the patient's life (Rivera et al. 2012). The chicken markets in Colombia, in most of the cases, do not meet the standards of good manufacturing practices (Flórez et al. 2008).

The aim of this study was to estimate the prevalence of Salmonella spp., circulating in chicken carcasses marketed at the Ibague city, during the period February to May 2014. The study also provides the main serotypes and identifies potential risk factors associated with Salmonella contamination.

\section{MATERIALS AND METHODS}

\section{Study design and sample collection}

Across-sectional study was conducted (between February and May 2014) to establish the prevalence of Salmonella spp. in broiler carcasses marketed at Ibague, department of Tolima, Colombia. The sample size was calculated by the formula described by Thrusfield (2007), with a 95\% confidence level, 5\% error, and an expected prevalence of $22.2 \%$, based on a pilot study conducted by our research group at the University of Tolima (unpublished data). For the purposes of this study, 270 samples were taken. The sampling included all the 13 communes that make up the Ibague city, and the number of samples per commune was proportional to the number of stores registered at the authority (Cámara de Comercio, Ibague). Each sample consisted of one drumstick of chicken weighing about $200 \mathrm{~g}$ that was randomly taken and immediately packaged in sterile airtight plastic bags, refrigerated on ice, and transported to the Laboratory of Veterinary diagnosis for processing within $3 \mathrm{hr}$.

\section{Epidemiological survey}

A questionnaire was designed and applied to shop owners during an interview at the time of sampling. The variables included in the survey followed those described in other studies (Carrasco et al. 2012; Donado-Godoy et al. 2012; Nguyen et al. 2014), and perfected in the pilot study conducted by our research group at the University of Tolima. The assessed variables are shown in Table 1. An epidemiological map was constructed to indicate the location and number of positive samples per commune using ArcGIS 10.1 version software.

\section{Salmonella isolation and serotyping.}

All samples were processed according to the standard international guidelines ISO 6579:2002; ISO 6579:2002/Amd1: 2007 (Reid, 2009). Briefly, samples were incubated in peptone-buffered water for preenrichment, with an incubation time of 24 hours at $37^{\circ} \mathrm{C}$, which were further seeded in tetrathionate broth (Müller-Kauffmann) and incubated at $37^{\circ} \mathrm{C}$ and in Rappaport Vassiliadis and incubated at $42^{\circ} \mathrm{C}$ for selective enrichment. Later cells were seeded on McConkey and XLT4 (Xylose Lysine Tergitol 4) agar. Compatible colonies were seeded in Rambach agar and confirmed as Salmonella spp, by challenge with antibodies Poli Al + Vi (Difco® 222641). Positive colonies were confirmed biochemically by using the API® 20E gallery (Biomereux, France). The isolates 
Table 1 - Variables and categories assessed to owner/administers of meat shops of Ibague, Tolima in an epidemiological survey.

\begin{tabular}{lll}
\hline VARIABLE & CATEGORIES & DESCRIPTION \\
\hline Storage type & Frozen & Temperature at time of collection of $-5^{\circ} \mathrm{C}$ \\
Source & Cooled & Temperature at the time of collection of $4-10^{\circ} \mathrm{C}$ \\
& Integrated Company & All production cycle is handled by one company \\
Market type & Non integrated company & Production cycle is handled by several companies \\
& Supermarkets and neighbor hoodstores & Facility where a variety of food products are marketed \\
Number of workers & Outlets & Retail stores that sell only meat and byproducts \\
& $>2$ & Presence of 1 to 2 persons at the time of sampling \\
Selling other meats & Yes & Presence of 3 or more people at the time of sampling \\
& No & Retail store that sell different types of meat \\
Storage surface & Stainless Steel & Retail store that only sell poultry meat and poultry byproducts \\
& Plastic & At sampling time, the meat is disposed on stainless steel \\
Production system & Conventional & At sampling time, the meat is disposed on plastic \\
& Free range & Poultry characterized by white skin after slaughter \\
Handling & Gloves & Poultry characterized by yellow skin after slaughter \\
& Skin & Meat is handled with gloves \\
\hline
\end{tabular}

were serotyped using the Kauffman-White scheme (Brenner, 1998), for $\mathrm{O}$ and $\mathrm{H}$ antigens with commercial antisera (Difco, Becton, Dickinson and Company Sparks, MD). Serotyping was performed based on the antigenic description by Grimont \& Weill (2007) and the nomenclature described by Tindall et al. (2005), and the Judicial Commission of the International Committee on Systematics of Prokaryotes (2005), and was carried out at the Colombian Institute of Agriculture (ICA).

\section{Polymerase chain reaction}

Salmonella isolates were seeded in tryptone soy broth (TSB), and incubated for $24 \mathrm{~h}$ at $37{ }^{\circ} \mathrm{C}$. Crude DNA was prepared by boiling a culture broth of bacteria for 10 minutes, incubated on ice for a few minutes and then centrifuged at 12,500 rpm for 5 minutes to pellet the particulate matter. The supernatant was collected as crude DNA and $4 \mu$ l were used as template in the PCR mixture to amplify the invA gene by using the forward 5'-GTG AAA TTA TCG CCA CGT TCG GGC AA-3' and reverse 5'-TCA TCG CAC CGT CAA AGG AAC C-3' primers (Invitrogen ${ }^{\mathrm{TM}}$, Thermo Fisher Scientific Inc.) with and expected amplicon size of $284 \mathrm{bp}$.

PCR was carried out in a total volume of $25 \mu \mathrm{L}$ containing $4 \mu \mathrm{L}$ of template DNA, $1 \mu \mathrm{L}$ of forward primer, $1 \mu \mathrm{L}$ of reverse primer, $0,2 \mu \mathrm{L}$ of Taq polymerase, $2,5 \mu \mathrm{L}$ of buffer $10 \mathrm{X}, 2,5 \mu \mathrm{L}$ of $\mathrm{MgCl}_{2}, 13,8 \mu \mathrm{L}$ of nuclease free water was also added. PCR was performed in a DNA thermal cycler BIO-RADT100'M, after initial denaturation of 1 minute at $94^{\circ} \mathrm{C}, 35$ cycles of amplification were performed. Each cycle consisted of the following steps: 60 seconds at $94^{\circ} \mathrm{C}$ (denaturation), 30 seconds at $64^{\circ} \mathrm{C}$ (primer annealing), and 30 seconds at $72^{\circ} \mathrm{C}$ (extension), followed by 7 minutes at $72^{\circ} \mathrm{C}$ for final extension. Salmonella Typhimurium (ATCC 14028) was used as a positive control, whereas the negative control did not contain DNA template. The reaction mixture was mixed with $10 \times$ gel loading buffer and then resolved by electrophoresis on $2 \%$ agarose gel with 100 bp DNA ladder. The reaction products were stained with ethidium bromide and visualized under the UV light by using an ENDURO ${ }^{\mathrm{TM}}$ GDS (Labnet International, Inc.), GEL documentation system.

\section{Statistical Analysis}

Data were analyzed in the IBM SPSS Statistics $₫ 20$ version software, and GraphPad Prism ${ }^{\circledR} 5.03$ version software. Independence between the variables and the presence of Salmonella was determined by using $2 \times 2$ contingency tables. The strength of association was calculated by the odds ratio. Prevalence was determined as the proportion of positive samples over the total samples, expressed as a percentage.

\section{RESULTS}

The prevalence of Salmonella spp., in poultry carcasses marketed at Ibague, Tolima was $17.41 \%$ (47/270). Isolation of Salmonella was slightly higher from supermarkets and small neighborhood stores $(42.5 \% ; 20 / 47)$, than outlets $(57.5 \% ; 27 / 47)$, however, there were no statistically significant differences. $57.5 \%$ (27/47) of Salmonella were isolated from stores with more than two workers, and from stores where different types of meats are sold. Salmonella was also isolated with more frequency from non-integrated companies $65,96 \%$ (31/47) than integrated ones. 


\section{Serotypes of Salmonella in Broiler Carcasses Marketed at Ibague, Colombia.}

Regarding the source of the poultry contaminated carcasses, $78.7 \%$ (37/47) originated from free-range production systems, $51.1 \%$ (24/47) were handled without gloves and $91.5 \%$ (43/47) were kept in refrigeration. Finally, the majority of isolates $(97.9 \%$, 46/47) were obtained from chickens that had been in contact with stainless steel surfaces. The number of isolates per commune is shown in Figure 1, where communes 12 and 13 were Salmonella free.

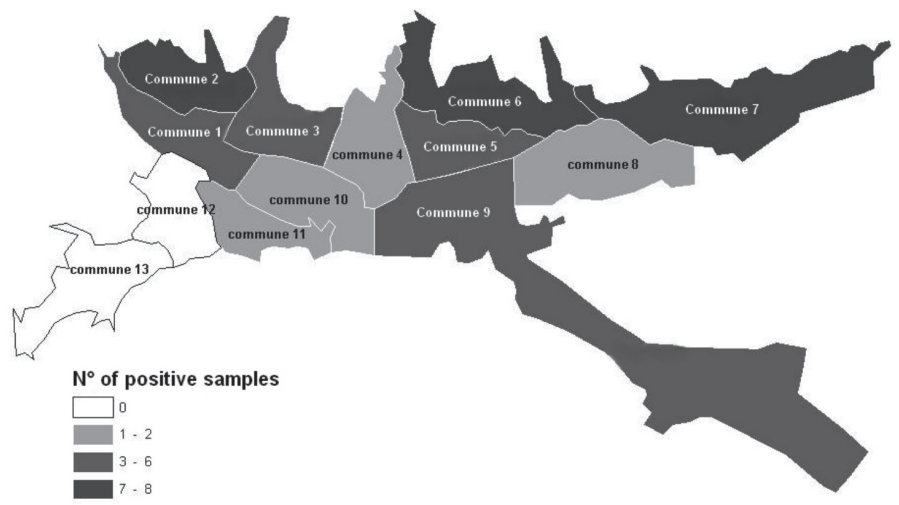

Figure 1. Number of positive samples per commune of the Ibague city.

The most frequently isolated Salmonella serotypes were S. Paratyphi B (36.17\%; 17/47), Hvittingfoss (19.15\%;9/47), and Muenster (10.64\%; 5/47). The serotypes Typhimurium, Newport, Heidelberg, Braenderup, and Kalina were found at a frequency of 4.26\% (2/47) each, while Bovismorbificans, Budapest, Manhattan, Othmarschen, Schwarzengrund, and Skansen were found at a lower frequency $(2.13 \% ; 1 / 47)$ for each serotype.

A number of Salmonella isolates were selected for detection of the invasion A gene (InvA) by using polymerase chain reaction. Figure 2 shows a representative image of the $P C R$ results where the expected $284 \mathrm{bp}$ band of the invA gene of Salmonella was present in all selected isolates.

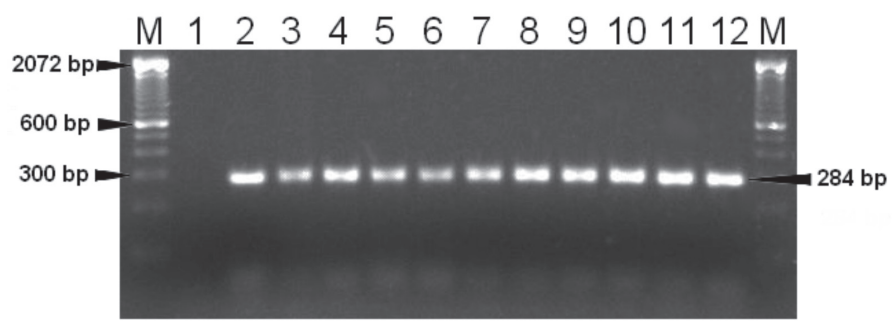

Figure 2 - PCR amplification of invA gene in selected isolates. Lane M represents 100bp molecular weight marker, lane 1 represent negative control, lane 2 represent positive control (Salmonella Typhimurium), lanes $3-12$ represent selected isolates.

Among the variables evaluated, the outlets that sold only meat and byproducts (OR: $2.157, p<0.05$ ) and the presence of stainless steel as the contact surface (OR: 13.29, $p<0.05$ ) were identified as risk factors for the presence of Salmonella spp., in the chicken carcasses marketed in Ibague, Tolima. Likewise, keeping the chicken meat refrigerated (OR:1.7) and the source of chicken meat from nonintegrated companies (OR:1.5) may also affect the presence of Salmonella; however, those differences were not significant ( $p>0.05)$. On the other hand and contrary to what was expected, handling of carcasses without any protection by workers was not associated ( $p>0.05$ ) with the presence of Salmonella. Table 2 shows the distribution of isolates and potential risk factors for the presence of Salmonella in chicken meat marketed at Ibague, Tolima.

Table 2 - Risk factors and frequency distribution of Salmonella in chicken meat marketed at Ibague Tolima.

\begin{tabular}{|c|c|c|c|c|}
\hline VARIABLE & $\begin{array}{l}\text { No. (\%) OF } \\
\text { POSITIVE } \\
\text { SAMPLES }\end{array}$ & $\mathrm{OR}^{*}$ & $\mathrm{Cl}^{* * 95 \%}$ & $P$ \\
\hline \multicolumn{5}{|l|}{ Storage type } \\
\hline Cooled & $43(18.3)$ & 1.736 & $\begin{array}{c}0.5819- \\
5.177\end{array}$ & 0.4728 \\
\hline Frozen & $4(11.43)$ & & & \\
\hline \multicolumn{5}{|l|}{ Source } \\
\hline $\begin{array}{l}\text { Nonintegrated } \\
\text { Company }\end{array}$ & $31(20)$ & 1.547 & $\begin{array}{c}0.8005- \\
2.989\end{array}$ & 0.2557 \\
\hline Integrated Company & $16(13.91)$ & & & \\
\hline \multicolumn{5}{|l|}{ Market type } \\
\hline Outlet & $27(17.76)$ & 1.058 & $\begin{array}{c}0.5603- \\
1.999\end{array}$ & 1 \\
\hline Supermarket & 20 (16.95) & & & \\
\hline \multicolumn{5}{|l|}{ Number of workers } \\
\hline$<,=2$ & $27(15.43)$ & 0.6841 & $\begin{array}{c}0.3601- \\
1.300\end{array}$ & 0.2452 \\
\hline$>2$ & $20(21.05)$ & & & \\
\hline \multicolumn{5}{|l|}{ Selling other meats } \\
\hline no & $20(25.97)$ & 2.157 & $\begin{array}{l}1.124- \\
4.141\end{array}$ & 0.0317 \\
\hline yes & 27 (13.99) & & & \\
\hline \multicolumn{5}{|l|}{ Storage surface } \\
\hline Stainless steel & $46(21)$ & 13.29 & $\begin{array}{l}1.788- \\
98.88\end{array}$ & 0.0004 \\
\hline Plastic & $1(1.96)$ & & & \\
\hline \multicolumn{5}{|l|}{ Production system } \\
\hline Free range & $37(17.62)$ & 1.069 & $\begin{array}{c}0.4969- \\
2.301\end{array}$ & 1 \\
\hline Conventional & $10(16.67)$ & & & \\
\hline \multicolumn{5}{|l|}{ Handling } \\
\hline Skin & $24(14.37)$ & 0.5838 & $\begin{array}{c}0.3096- \\
1.101\end{array}$ & 0.1009 \\
\hline Gloves & 23 (22.33) & & & \\
\hline
\end{tabular}

${ }^{*}$ OR: Odds ratio; ${ }^{*} \mathrm{Cl}$ : Confidence interval 

at Ibague, Colombia.

\section{DISCUSSION}

Salmonella spp., was isolated from $17.41 \%$ of chicken samples (47/270) marketed in Ibague, Tolima, and a number of serotypes were identified and confirmed by amplification of a fragment of the invA gene using PCR (Galan, Curtiss, 1991; Li et al., 2012; O'Regan et al., 2008; Shanmugasamy et al., 2011), a rapid and powerful technique used for Salmonella identification (Cardona-castro et al., 2007; Ibrahim et al., 2014; Molina et al., 2010; Tafida et al., 2013). Thus, this data is a representative estimation of the occurrence of Salmonella in a region with traditional poultry industry and it may indicate poor hygienic and disinfection practices, which have been associated with cross-contamination and recontamination of poultry carcasses (Carrasco et al. 2012).

This prevalence is higher than that reported in raw chicken (5.26\%; $n=209$ ) sold in Bangkok, Thailand (Akbar, Kumar, 2013), and in chicken at slaughter plants $(7.52 \% ; n=425)$ in France (Hue et al., 2011). Those differences may be due to differences in market conditions (e.g., production volume, cold chain) and regulations in each country. Previously in Colombia, Donado-Godoy et al. (2012) estimated a Salmonella prevalence of $27 \%(n=1003)$ in chicken carcasses marketed at differentstores across the country; however, the number of samples taken at the chicken market in Ibague $(n=27)$ was considerably low, suggesting that this prevalence may not be representative of this city. The prevalence of Salmonella in this study is very close to that reported in raw chicken $(20 \% ; n=45)$ marketed in Mérida, Venezuela (Molina et al., 2010), and significantly lower than the prevalence (41.6\%) reported in chicken meat marketed in 6 provinces of China (Zhu et al., 2014), where other studies also have documented a prevalence of Salmonella up to $54 \%(n=515)$ by using molecular techniques such as PCR (Yang et al., 2010). These studies reveal that the prevalence of Salmonella in chicken meat may vary dramatically between distinct geographical regions based on the use of more sensitive diagnostic techniques.

Salmonella serovar Enteritidis and Typhimurium are the main serotypes isolated from poultry (Ibrahim et al., 2014; Kim, 2010). In the present study, Salmonella ser. Paratyphi B was the most prevalent in chicken meat, consistently with the report of Boscán et al. (2005), who isolated the bacteria from chicken viscera in two slaughter plants in the state of Zulia, Venezuela, and the report by Barua et al. (2013), who isolated this serotype from breeders and broiler farms in Bangladesh. S. Paratyphi B is known to be adapted to commercial poultry (Toboldt et al., 2013; van de Giessen et al., 2006; Van Immerseel et al., 2004), and it can be isolated from farm to store (Egervärn et al., 2014). S. Muenster has been isolated from pork sausages (Torres et al., 2013), ground beef (Bosilevacet al., 2009), cheese from goat milk (Van Cauteren et al., 2009), pork and poultry (Meneses, 2010). In our study, S. Muenster represented $10.64 \%$ (5/47) of isolates, which is similar to the study of Khallaf et al. (2014), who found $13 \%(5 / 38) \mathrm{S}$. Muenster in chicken meat samples. The serotypes found in our study differ from those reported in egg-laying hen farms in the Tolima region of Colombia by Rodriguez et al. (2015), who identified S. Enteritidis and S. Shannon. Taken together, these studies show diverse geographical distribution of Salmonella serovars in poultry and byproducts as well as in other kind of meats, and highlight the importance of contamination from farm and the crosscontamination in the stores and slaughter plants.

The serotypes Salmonella Paratyphi, S. Typhimurium, S. Newport, S. Heidelberg, S. Braenderup, and S. Schwarzengrund found in our study have previously been associated with outbreaks of disease in humans (CDC, 2014). Likewise, Salmonella Typhimurium, S. Branderup, and S. Muenster have been associated with foodborne outbreaks in Colombia (National Institute of Health, 2011), suggesting a potential link between poultry and salmonellosis in this region. However, the impact of Salmonella in the Tolima region has not been currently addressed.

Marketing of poultry carcasses as the only type of meat sold in a store was found as a potential risk factor for Salmonella contamination (Odds ratio: 2.157, p $<0.05)$, which is consistent with the report of Hue et al. (2011), who found that the slaughtering of the species Gallus gallus alone was a risk factor for Salmonella contamination in France (OR: 7.08, p <0.001). The argument for this finding was that the sacrifice of various animal species demands stricter hygiene measures and better organization than processing a single species. Similarly, stores that sell meat from different species may involve more employees than those that sell meat from a single species. Nevertheless, opposite situations were reported by Acosta et al. (2013), who argued that a higher prevalence of Salmonella spp. in meat than other foods may be due to contamination of carcasses by handlers (Gomes-Neves et al., 2014). In our study, the number of workers at the chicken meat shop did not represent a statistically significant risk factor. 
The serotype of Salmonella and the hydrophobicity of the contact surface may positively influence the adhesion process (Chia et al. 2009; Pérez-Rodríguez et al. 2008), and Salmonella has a greater adhesion capacity to surfaces made of stainless steel than plastic and acrylic (Chia et al., 2009; Nguyen et al., 2014), where it may be able to form biofilms (Tammakritsada \& Todhanakasem, 2012; Giaouris et al. 2012). This study found that the contact of chicken meat with surfaces made of stainless steel was a risk factor (odds ratio: $13.29, p<0.05)$ for Salmonella contamination, suggesting that disinfection of equipment made of stainless steel may be insufficient, given that biofilms formed on stainless steel are more sensitive to disinfectants than those adhered to plastic (Joseph et al., 2001). Another possible reason for those findings could be the misuse of disinfection protocols and the use of disinfectant concentrations below the recommended level, inadequate exposure time, among other variables that may influence the effectiveness of disinfectants (Møretrø et al. 2012). Recently, Wang et al. (2015) reported biofilms of Salmonella on stainless steel surfaces that facilitated the transfer of the bacteria to meat products, and Arcos-Ávila et al. (2013) isolated Salmonella from fomites, such as knives, and counters made of stainless steel. This highlights the importance of implementing rigorous protocols for cleaning and disinfecting equipment and tools, as well as microbiological sampling to verify if these protocols fulfill their aims, in addition of creating awareness in food-handling staff.

Salmonella was isolated in $68.08 \%$ of samples from nonintegrated companies suggesting that contamination may involve different people during the marketing process. Nonintegrated companies was reported as a risk factor (OR: 2.0, $p$ <0.001) for Salmonella contamination in Colombia (DonadoGodoy et al. 2012). However, this was not the case in the present study, and therefore, the impact of this variable needs to be evaluated to establish whether the quality and control measures at each step of the production chain are indeed reduced in nonintegrated companies. Finally, the majority of sampled stores sold chilled carcasses $(87.41 \%)$, but this variable was not identified as a risk factor, contrary to previous studies (Donado-Godoy et al., 2012; Zhu et al.,2014). The reason for those results are currently unknown; however, attention and efforts should be focused on the time of refrigeration of carcasses, as well as in the rate of replacement of old carcasses by fresh ones, that may influence the presence of Salmonella.
In conclusion, this study estimated for the first time a prevalence of $17.4 \%$ Salmonella in raw chicken meat marketed at Ibague, Tolima, where S. Paratyphi B, a well-known cause of human salmonellosis (Toboldt et al. 2013), was the most frequently isolated serotype, followed by Hvittingfoss and Muenster and by Typhimurium, Heidelberg, Braenderup, and Newport in terms of frequency. Selling raw chicken meat as the single meat type in the store and the use of stainless steel as a contact surface were found to be potential risk factors for Salmonella contamination, although they appear to be related to the hygienic measures and proper cleaning and disinfection, respectively. Thus, the information provided in this study may be used as a reference of the hygienic status of raw chicken marketed in this location and emphasizes the need to develop appropriate control and contingency measures to minimize the presence of Salmonella in chicken meat and its potential transmission to humans.

\section{ACKNOWLEDGEMENTS}

This research study was funded by grants from the Central Research Office of the University of Tolima to Noel Verjan García (Project No. 980213). The authors thank the owners of shops and stores that participated in the study, to Dr. Clemencia Fandiño for technical assistance in Salmonella isolation and laboratory technicians for their help during the analysis.

\section{REFERENCES}

Acosta L, Pinedo J, Hernández E, Villarreal J. Comparison between the Vitek immunodiagnostic Assay System and PCR for the detection of Salmonella spp. in foods. Salud Uninorte 2013;29(2):174-182.

Akbar A,Kumar A. Prevalence and antibiogram study of Salmonella and Staphylococcus aureus in poultry meat. Asian Pacific Journal of Tropical Biomedicine 2013;3(2):163-168.

Arcos-ávila EC, Mora-Cardona L, Fandiño-de Rubio LC, Rondon-Barragan IS Prevalencia de Salmonella spp. en carne porcina, plantas de beneficio y expendios del Tolima. Orinoquia 2013;17(1):59-68.

Barua $\mathrm{H}$, Biswas PK, Olsen KEP, Shil SK, Christensen JP. Molecular characterization of motile serovars of Salmonella enterica from breeder and commercial broiler poultry farms in Bangladesh. Plos One 2013;8(3):e57811.

Bosilevac JM, Guerini MN, Kalchayanand N, Koohmaraie M. Prevalence and characterization of Salmonellae in commercial ground beef in the United States. Applied and Environmental Microbiology 2009;75(7):1892-1900.

Brenner FW. Modified Kauffmann-White scheme. Atlanta: Centers for Disease Control and Prevention; 1998.

Brown DJ, Mather $\mathrm{H}$, Browning LM, Coia JE. Investigation of human infections with Salmonella enterica serovar java in Scotland and possible association with imported poultry. Eurosurveillance 2003;8(2):1-9. 


\section{Serotypes of Salmonella in Broiler Carcasses Marketed at Ibague, Colombia.}

Cardona-Castro NM, Sánchez-Jiménez MM, Usuga-Silva LY, Arboledanaranjo M, Garzón E, Vélez A, et al. Caracterización de dos brotes de fiebre tifoidea en Apartadó, Antioquia, 2005. Biomédica 2007;27:236243.

Carrasco E, Morales-Rueda A, García-Gimeno RM. Cross-contamination and recontamination by Salmonella in foods:A review. Food Research International 2012;45:545-556.

Centers for Disease Control and Prevention. Reports of selected Salmonella Outbreak Investigations 2014.Available from: http://www.cdc.gov/ salmonella/outbreaks.html

Chen M, Chiou C, Chiang Y, Chen P, Tsa S, Tsen H. Comparison of the pulsed fi eld gel electrophoresis patterns and virulence pro fi les of the multidrug resistant strains of Salmonella enterica serovar Schwarzengrund isolated from chicken meat and humans in Taiwan. Food Research International 2012;45(2):978-983.

Chia TW, Goulter RM, McMeekin T, Dykes G, Fegan N. Attachment of different Salmonella serovars to materials commonly used in a poultry processing plant. Food Microbiology 2009;26:853-859.

Boscan LA, Arzálluz AM, Ugarte Cl, Sánchez D, Diaz D, Wittum TE, et al. Aislamiento de Salmonella de importancia zoonótica en vísceras de pollos beneficiados en el Estado Zulia, Venezuela. Revista Científica FCV-LUZ 2005;15(6):576-582.

Díaz MÁ, Díaz PL, Rodríguez EC, Montaño LA, Medina MI, González Gl, et al. Caracterización fenotípica y genotípica de Salmonella Typhimurium variante 5- asociada a un brote de enfermedad transmitida por alimentos en el municipio de Paz de Río, Boyacá, 2010. Latreia $2014 ; 27(1): 23-30$.

Donado-Godoy P, Clavijo V, León M, Tafur MA, Gonzales S, Hume M, et al. Prevalence of Salmonella on Retail Broiler Chicken Meat Carcasses in Colombia. Journal of Food Protection 2012;75(6):1134-1138.

Egervärn M, Börjesson S, Byfors S, Finn M, Kaipe C, Englund S, et al. Escherichia coli with extended-spectrum beta-lactamases or transferable AmpC beta-lactamases and Salmonella on meat imported into Sweden. International Journal of Food Microbiology 2014;171:814.

El-Aziz D. Detection of Salmonella typhimurium in retail chicken meat and chicken giblets. Asian Pacific Journal of Tropical Biomedicine 2013;3(9):678-681.

Flórez AC, Rincón C, Garzón P, Vargas N, Enriquez C. Factores relacionados con enfermedades transmitidas por alimentos en restaurantes de cinco ciudades de Colombia, 2007. Infectio 2008;12(4):255-266.

Galan JE, Curtiss R. Distribution of the invA, $-B,-C$, and $-D$ genes of Salmonella typhimurium among other Salmonella serovars: invA mutants of Salmonella typhi are deficient for entry into mammalian cells. Infection and Immunity 1991;59(9):2901-2908.

Giaouris E, Chorianopoulos N, Skandamis P, Nychas G. Attachment and biofilm formation by Salmonella in food processing environments. In: Mahamoud BS, editor. Salmonella - a dangerous foodborne pathogen. Rijeka:Intech Open Access Publisher; 2012. p.157-180.

Gomes-Neves E, Antunes P, Manageiro V, Gärtner F, Caniça M, Correia JM, et al. Clinically relevant multidrug resistant Salmonella enterica in swine and meat handlers at the abattoir. Veterinary Microbiology 2014;168(1):229-233.

Gómez CC, Zuñiga E. Abscesos esplénicos por Salmonella. Acta Médica Colombiana 2005;30(3):123-125.

Grimont P,Weill F. Antigenic formulae of the Salmonella serovars. 9th ed. WHO Collaborating Centre for Reference and Research on
Salmonella; 2007. Available from: www.pasteur.fr/ip/portal/action/ WebdriveActionEvent/oid/01s-000036-089

Hue O, Le Bouquin S, Lalande F, Allain V, Rouxel S, Petetin I, et al. Prevalence of Salmonella spp. on broiler chicken carcasses and risk factors at the slaughterhouse in France in 2008. Food Control 2011;22(8):11581164

Ibrahim W, Abd El-Ghany W, Nasef S,Hatem ME. A comparative study on the use of real time polymerase chain reaction (RT-PCR) and standard isolation techniques for the detection of Salmonella in broiler chicks. International Journal of Veterinary Science and Medicine 2014;2(1):6771.

INFOSAN. Resistencia antimicrobiana a Salmonella. Red Internacional de Autoridades de Inocuidad de los Alimentos. Availablefrom: http://www. who.int/foodsafety/fs_management/No_03_Salmonella_Apr05_sp.pdf

Jiménez C, Valencia, A, Jaramillo C, Correa JR. Aneurisma aórtico bacteriano por Salmonella spp. Revista Colombiana de Cirurgia 2011;26:214-221.

Joseph B, Otta, SK, Karunasagar I, Karunasagar I. Biofilm formation by Salmonella spp. on food contact surfaces and their sensitivity to sanitizers. International Journal of Food Microbiology 2001;64:367372 .

Judicial Commission of the International Committee on Systematics of Prokaryotes. The type species of the genus Salmonella Lignieres 1900 is Salmonella enterica (ex Kauffmann and Edwards 1952) Le Minor and Popoff 1987, with the type strain LT2T, and conservation of the epithet enterica in Salmonella enterica over all earlier epithets t. International Journal of Systematic and Evolutionary Microbiology 2005;55:519-520.

Khallaf M, Ameur N, Terta M, Lakranb M, Senouci S, Ennaji M. Prevalence and antibiotic-resistance of Salmonella isolated from food in Morocco. International Journal of Innovation and Applied Studies 2014;6(4):1123-1128

Kim S. Salmonella serovars from foodborne and waterborne diseases in Korea, 1998-2007: total isolates decreasing versus rare serovars emerging. Journal of Korean Medical Science 2010;25(12):1693-1699.

Li Q, Cheng W, Zhang D, Yu T, Yin Y, Ju H, et al. Rapid and sensitive strategy for Salmonella detection using an InvA gene-based electrochemical DNA sensor. International Journal of Electrochemical Science 2012;7:844-856.

Majowicz SE, Musto J, Scallan E, Angulo FJ, Kira M, O’Brien SJ, et al. The global burden of nontyphoidalSalmonella gastroenteritis. Clinical Infectious Diseases 2010;50:882-889

Meneses YE. Identification and characterization of Salmonella serotypes isolated from pork and poultry from commercial sources. 2010. Available from: http://digitalcommons.unl.edu/foodscidiss/8

Mercado M, Ávila J, Rey M, Montoya M, GamboaA, Carrascal AK, et al.. Brotes por Salmonella spp., Staphylococcus aureus y Listeria monocytogenes asociados al consumo de pollo. Biomédica 2012;32:375-385.

Molina N, Millán B,Araque M. Indicadores de calidad sanitaria y fenotipificación de Salmonella enterica aislada de pollo crudo comercializado en el área urbana de Mérida, Venezuela. Infectio 2010;14(3):174-185.

Møretrø T, Heir E, Nesse LL, Vestby LK, Langsrud S. Control of Salmonella in food related environments by chemical disinfection. Food Research International 2012;45(2):532-544.

National Institute of Health. Perfil de riesgo Salmonella spp. (no tifoideas) en pollo entero y en piezas. UERIA 2011. Available from: http://www.ins. gov.co/lineas-de-accion/investigacion/ueria/Publicaciones/PERFIL \%20 SALMONELLA\%20SPP.pdf 


\section{Serotypes of Salmonella in Broiler Carcasses Marketed at Ibague, Colombia.}

Nguyen HD, Yang YS, Yuk HG. Biofilm formation of Salmonella Typhimurium on stainless steel and acrylic surfaces as affected by temperature and pH level. LWT - Food Science and Technology 2014;55(1):383-388.

O'Regan E, McCabe E, Burgess C, McGuinness S, Barry T, Duffy G, et al. Development of a real-time multiplex PCR assay for the detection of multiple Salmonella serotypes in chicken samples. BMC Microbiology 2008:8:156.

Pérez-Rodríguez F, Valero A, Carrasco E, García RM, Zurera G. Understanding and modelling bacterial transfer to foods: a review. Trends in Food Science and Technology 2008;19:131-144.

Reid A. Isolation and identification of Salmonella from food and environmental samples. Ottawa: Health Products And Food Branch;2009.

Rivera LG, Motta PA, Cerón MF, Chimonja FA. Resistance of Salmonella to conventional antimicrobials for their treatment. Revista CES Medicina Veterinaria y Zootecnia 2012;7(1):115-127.

Rodriguez R, Fandiño C, Donado P, Guzmán L, Verjan N. Characterization of Salmonella from commercial egg-laying hen farms in a central region of Colombia. Avian Diseases 2015;59:57-63.

Santos RL, Zhang S, Tsolis RM, Kingsley R, Adams LG, Bäumler AJ. Animal models of Salmonella infections: enteritis versus typhoid fever. Microbes and Infection 2001;3:1335-1344.

Shanmugasamy M, Velayutham T, Rajeswar J. InvA gene specific pcr for detection of Salmonella from broilers. Veterinary World 2011;4(12):562564.

Smadi H, Sargeant JM, Shannon HS, Raina P. Growth and inactivation of Salmonella at low refrigerated storage temperatures and thermal inactivation on raw chicken meat and laboratory media: mixed effect meta-analysis. Journal of Epidemiology and Global Health 2012;2(4):165-179.

Tafida SY, Kabir J, Kwaga JK, Bello M, Umoh VJ, Yakubu SE, et al. Occurrence of Salmonella in retail beef and related meat products in Zaria, Nigeria. Food Control 2013;32(1):119-124.

Tammakritsada M, Todhanakasem T. Isolation of Salmonella from natural sources representing high potential for biofilm formations. AU JournalTechnology 2012;15(4):225-232.
Tindall BJ, Grimont PD, Garrity GM, Euzéby JP. Nomenclature and taxonomy of the genus Salmonella. International Journal of Systematic and Evolutionary Microbiology 2005;55:521-524.

Toboldt A, Tietze E, Helmuth R, Junker E, Fruth A, Malorny B. Population structure of Salmonella enterica serovar 4,[5],12:b:- strains and likely sources of human infection. Applied and Environmental Microbiology 2013:79(17):5121-5129.

Torres M, Ovono D, Hugues B,Amaro B. Incidencia de Salmonella en diferentes tipos de productos cárnicos. REDVET. Revista Electrónica de Veterinaria 2013;14(11B):1-5.

Thrusfield M. Veterinary epidemiology. 3rded. Oxford: Blackwell Science; 2007. p.182-184

Van Cauteren D, Da Silva NJ, Weill FX, King L, Brisabois A, Delmas G, et al. Outbreak of Salmonella enterica serotype Muenster infection associated with goat's cheese, France, March 2008. Eurosurveillance 2009:14(31):1-3.

Van de Giessen AW, Bouwknegt M, Dam-Deisz WD, Van Pelt W, Wannet WJ, Visser G. Surveillance of Salmonella spp. and Campylobacter spp. in poultry production flocks in The Netherlands. Epidemiology and Infection 2006;134(6):1266-1275.

Van immerseel F, Meulemans L, De Buck J, Pasmans F, Velge P, Bottreau E, et al. Bacteria - host interactions of Salmonella Paratyphi B dT + in poultry. Epidemiology and Infection 2004;132:239-243.

Wang H, Zhang X, Zhang Q,, Ye K, Xu X,Zhou G. Comparison of microbial transfer rates from Salmonella spp. biofilm growth on stainless steel to selected processed and raw meat. Food Control 2015;50:574-580.

Yang B, Qu D, Zhang X, Shen J, Cui S, Shi Y, et al. Prevalence and characterization of Salmonella serovars in retail meats of marketplace in Shaanxi, China. International Journal of Food Microbiology 2010;141(1):63-72

Zhu J, Wang Y, Song $X$, Cui S, Xu H, Yang B, et al. Prevalence and quantification of Salmonella contamination in raw chicken carcasses at the retail in China. Food Control 2014;44:198-202. 